\title{
The uncertainty of climate sensitivity and its implication for the Paris negotiation
}

\author{
Yoichi Kaya $^{1} \cdot$ Mitsutsune Yamaguchi $^{1} \cdot$ Keigo Akimoto $^{1}$
}

Received: 4 August 2015/ Accepted: 12 September 2015/Published online: 23 September 2015

(C) Springer Japan 2015

\begin{abstract}
Uncertainty of climate sensitivity is one of the critical issues that may affect climate response strategies. Whereas the equilibrium climate sensitivity (ECS) was specified as $2-4.5{ }^{\circ} \mathrm{C}$ with the best estimate of $3{ }^{\circ} \mathrm{C}$ in the 4th Assessment Report of IPCC, it was revised to $1.5-4.5^{\circ} \mathrm{C}$ in the 5th Assessment Report. The authors examined the impact of a difference in ECS assuming a best estimate of $2.5^{\circ} \mathrm{C}$, instead of $3{ }^{\circ} \mathrm{C}$. The current pledges of several countries including the U.S., EU and China on emission reductions beyond 2020 are not on track for the $2{ }^{\circ} \mathrm{C}$ target with an ECS of $3{ }^{\circ} \mathrm{C}$ but are compatible with the target with an ECS of $2.5^{\circ} \mathrm{C}$. It is critically important for policymakers in Paris to know that they are in a position to make decisions under large uncertainty of ECS.
\end{abstract}

Keywords Uncertainty - Equilibrium climate sensitivity · Paris climate conference . Intended nationally determined contributions $\cdot 2{ }^{\circ} \mathrm{C}$ target

By the end of June, 2015, the United States, the European Union, China and several other countries submitted their intended nationally determined contributions (INDCs) to the UNFCCC secretariat. This is a good start toward the coming Paris climate conference (COP 21). However, according to our estimate based on our global energy systems model DNE21+ (Akimoto 2008) and a simple climate change model MAGICC (Meinshausen et al. 2011),

Handled by Yoshiyuki Shimoda, Osaka University, Japan.

Keigo Akimoto

aki@ rite.or.jp

1 Research Institute of Innovative Technology for the Earth (RITE), 9-2 Kizugawadai, Kizugawa-shi, Kyoto 619-0292, Japan these pledges are nowhere near sufficient to limit the temperature increase to less than $2{ }^{\circ} \mathrm{C}$ since pre-industrialization if we apply $3{ }^{\circ} \mathrm{C}$ as the best estimate ${ }^{1}$ of the equilibrium climate sensitivity (ECS).

ECS is defined as an increase in global mean surface temperature caused by a doubling of the atmospheric $\mathrm{CO}_{2}$ concentration. The uncertainty of climate sensitivity poses one of the greatest challenges in planning strategies on how and to what extent we should cope with risks of climate change.

Throughout IPCC's 1st to 3rd Assessment Report, the likely range of ECS was estimated as $1.5-4.5^{\circ} \mathrm{C}$ with its best estimate at $2.5^{\circ} \mathrm{C}$. The 4 th Assessment Report (AR4) specified a likely range (greater than $66 \%$ probability) of ECS as $2-4.5^{\circ} \mathrm{C}$ with its "most likely value" or "best estimate" of $3{ }^{\circ} \mathrm{C}$, but the 5 th Assessment Report (AR5) lowered the figure to $1.5-4.5{ }^{\circ} \mathrm{C}$. In addition, no best estimate was given by AR5 because of the difference of methodologies of estimating ECS as explained below (IPCC 2013).

According to the estimates of atmosphere-ocean general circulation models (AOGCMs) in the AR5, the mean value of ECS is $3.2{ }^{\circ} \mathrm{C}$ and the ranges is $2.0-4.5^{\circ} \mathrm{C}$, close to that in the AR4. Climate sensitivity can also be estimated from observations of surface temperature and climate forcing data. The values of ECS thus estimated are rather lower as pointed out by Rogelj et al. and others (IPCC 2013, Lewis and Curry, 2014, Otto et al. 2013) and Lewis and Curry (2014) estimated the likely range of climate sensitivity as $1.25-2.45{ }^{\circ} \mathrm{C}$ with its median estimate at $1.64{ }^{\circ} \mathrm{C}$.

\footnotetext{
1 There is no definition of the word 'best estimate'. Often the word is used in the same meaning as 'most likely value'. Sometimes it is used as the same meaning as 'median' or 'mode'. IPCC (2013) states that best estimate and most likely value are defined in various ways in different studies.
} 
There are several criticisms of the observation-based methods, though, including one arguing that the observed warming is likely biased low (Durack et al. 2014).

We would like to examine the effect of uncertainty of ECS on emissions targets. Rogelj et al. (2014) admitting recent estimates based on the observed warming trends tend to show lower values of climate sensitivity, argues that "[T]here are several climate policy implications that can be drawn from recent ECS estimates. The most important, however, is that they do not change the big picture if all available evidence is taken into account. (...) Even the lowest ECS estimate assumed in this study only results in a delay of less than a decade in the timing of when the $2{ }^{\circ} \mathrm{C}$ threshold would be crossed when emission trends from the past 10 years are continued."

This conclusion, what we found, comes from the Supplementary Material of the paper. There, two ECS distributions, among others, were used for comparison; one was named as IPCC AR4 consistent and the other as IPCC AR5 consistent. By comparing those two, Rogelj et al. concluded that the differences of climate sensitivity 'do not change the picture'. What matters is that the median values of those two were almost the same, i.e., $3{ }^{\circ} \mathrm{C}$ for the former and $3.1{ }^{\circ} \mathrm{C}$ for the latter, though distribution itself is a little bit flat in AR5 consistent.

As pointed out previously, the likely range of ECS was lowered to $1.5-4.5^{\circ} \mathrm{C}$ (in AR5) from 2 to $4.5^{\circ} \mathrm{C}$ (in AR4), and experts were unable to agree on the value of the best estimate in AR5 though it was agreed as $3{ }^{\circ} \mathrm{C}$ in AR4. In addition, the value of $2.5^{\circ} \mathrm{C}$ had been used as best estimate (most likely value) throughout IPCC's 1st to 3rd assessment reports where the likely range of climate sensitivity had been $1.5-4.5^{\circ} \mathrm{C}$. Under the above situation, it is only natural to assume the best estimate (median) for AR5 will be lower than $3{ }^{\circ} \mathrm{C}$. Therefore, we chose the best estimate value of $2.5^{\circ} \mathrm{C}$ for the purpose of comparison to explore the impact of difference in ECS on climate negotiations. The point at issue here is whether INDCs submitted by major countries are consistent with the $2{ }^{\circ} \mathrm{C}$ target under different climate sensitivities. Note that it is not the authors' intention to argue $2.5{ }^{\circ} \mathrm{C}$ is the correct value.

Rogelj et al. (2012), Schaeffer et al. (2015) and IPCC (2014) calculated the temperature by MAGICC with the probabilistic mode for climate sensitivity by assuming its probability density function (Table 1). However, as the probabilistic mode of MAGICC is not accessible for

Table 1 Relationship between $\mathrm{CO}_{2}$ eq. concentrations, emissions reductions and temperature changes

\begin{tabular}{|c|c|c|c|c|c|c|c|}
\hline \multirow{3}{*}{$\begin{array}{l}\mathrm{CO}_{2} \text { eq Concentrations in } 2100 \\
{\left[\mathrm{ppm} \mathrm{CO}_{2} \text { eq] category label }\right.} \\
\text { (concentration range) }\end{array}$} & \multirow[t]{3}{*}{ Subcategories } & \multirow{3}{*}{$\begin{array}{l}\text { Cumulative } \\
\mathrm{CO}_{2} \text { emissions } \\
{\left[\mathrm{GtCO}_{2}\right]} \\
2011-2100\end{array}$} & \multirow{3}{*}{$\begin{array}{l}\text { Change in } \mathrm{CO}_{2} \text { eq } \\
\text { emissions } \\
\text { compared to } 2010 \\
2050(\%)\end{array}$} & \multicolumn{4}{|c|}{ Temperature change (relative to $1850-1900$ ) } \\
\hline & & & & \multirow[t]{2}{*}{$\begin{array}{l}2100 \\
\text { Temperature } \\
\text { change }\left[{ }^{\circ} \mathrm{C}\right]\end{array}$} & \multicolumn{3}{|c|}{$\begin{array}{l}\text { Likelihood of staying below } \\
\text { temperature level over the twenty } \\
\text { first century }\end{array}$} \\
\hline & & & & & $1.5^{\circ} \mathrm{C}$ & $2.0^{\circ} \mathrm{C}$ & $3.0^{\circ} \mathrm{C}$ \\
\hline $450(430-480)$ & Total range & $630-1180$ & -72 to -41 & $\begin{array}{l}1.5-1.7^{\circ} \mathrm{C} \\
(1.0-2.8)\end{array}$ & $\begin{array}{l}\text { More } \\
\text { unlikely } \\
\text { than } \\
\text { likely }\end{array}$ & Likely & Likely \\
\hline \multirow[t]{2}{*}{$500(480-530)$} & $\begin{array}{l}\text { No overshoot } \\
\text { of } 530 \mathrm{ppm} \\
\mathrm{CO}_{2} \mathrm{eq}\end{array}$ & $960-1430$ & -57 to -42 & $\begin{array}{l}1.7-1.9^{\circ} \mathrm{C} \\
(1.2-2.9)\end{array}$ & Unlikely & $\begin{array}{l}\text { More } \\
\text { likely } \\
\text { than not }\end{array}$ & \\
\hline & $\begin{array}{l}\text { Overshoot of } \\
530 \mathrm{ppm} \\
\mathrm{CO}_{2} \mathrm{eq}\end{array}$ & $990-1550$ & -55 to -25 & $\begin{array}{l}1.8-2.0{ }^{\circ} \mathrm{C} \\
(1.2-3.3)\end{array}$ & & $\begin{array}{l}\text { About as } \\
\text { likely as } \\
\text { not }\end{array}$ & \\
\hline \multirow[t]{2}{*}{$550(530-580)$} & $\begin{array}{l}\text { No overshoot } \\
\text { of } 580 \mathrm{ppm} \\
\mathrm{CO}_{2} \mathrm{eq}\end{array}$ & $1240-2240$ & -47 to -19 & $\begin{array}{l}2.0-2.2{ }^{\circ} \mathrm{C} \\
(1.4-3.6)\end{array}$ & & $\begin{array}{l}\text { More } \\
\text { unlikely } \\
\text { than }\end{array}$ & \\
\hline & $\begin{array}{l}\text { Overshoot of } \\
580 \mathrm{ppm} \\
\mathrm{CO}_{2} \text { eq }\end{array}$ & $1170-2100$ & -16 to +7 & $\begin{array}{l}2.1-2.3^{\circ} \mathrm{C} \\
(1.4-3.6)\end{array}$ & & likely & \\
\hline
\end{tabular}

The above table is an extract from Table SPM.1 from AR5 WG3 that shows information including the relationship between $\mathrm{CO}_{2}$ eq. concentrations and temperature changes in 2100

Temperature change in 2100 is provided for a median estimate of the MAGICC calculations, which illustrates differences between the emissions pathways of the scenarios in each category

The range of temperature change in parentheses includes, in addition, the carbon cycle and climate system uncertainties as represented by the MAGICC model

Note that the above figures are calculated based on a climate sensitivity of $3{ }^{\circ} \mathrm{C}$ (most likely value) 


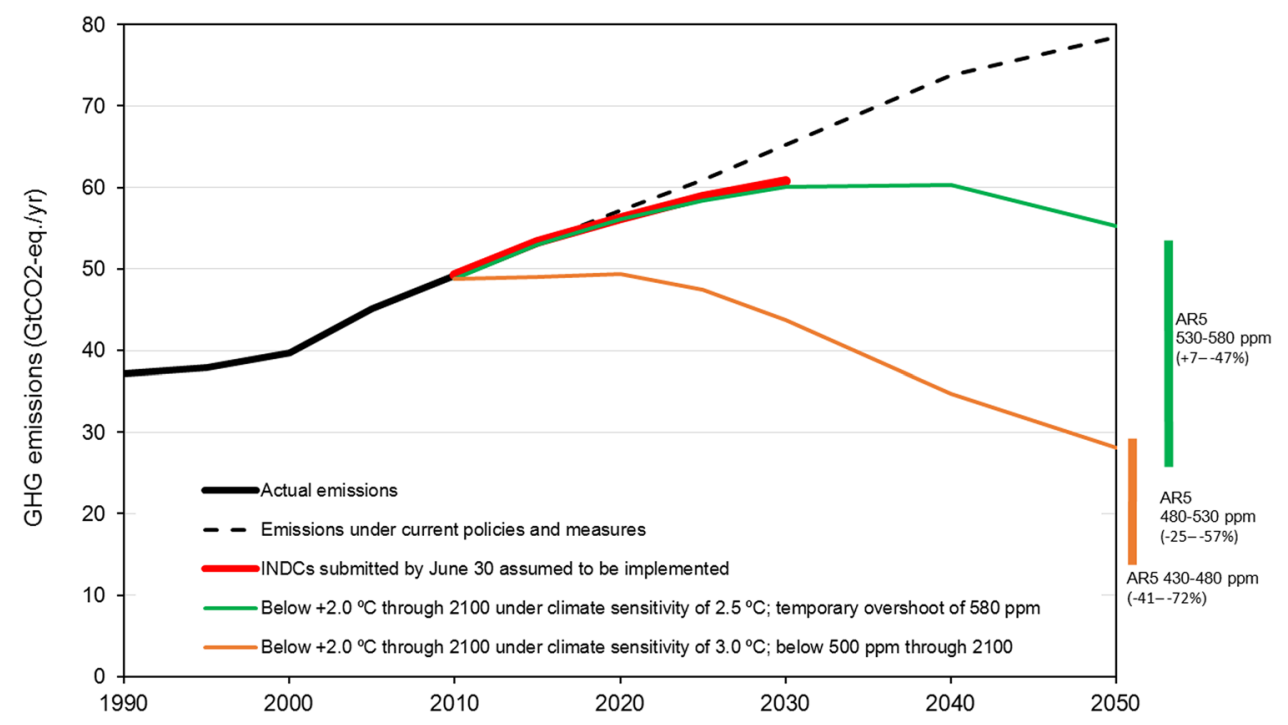

Fig. 1 Estimated emission pathways toward 2050 by the DNE21+ model (and MAGGC model) which is a global energy system model with 54 disaggregated regions and countries, and seeks cost-effective measures on emission reductions: Black dotted line shows the emissions pathway under current policies, green line shows the emissions pathway that limits the temperature increase below $2{ }^{\circ} \mathrm{C}$ through 2100 under a climate sensitivity of $2.5^{\circ} \mathrm{C}$, which corresponds to the scenario of a slight temporal overshoot of 580ppm $\mathrm{CO}_{2^{-}}$ eq. concentration in AR5. Temperature is expected to stabilize below $2{ }^{\circ} \mathrm{C}$ in the long run. Orange line shows the emissions pathway that limits the temperature increase to below $2{ }^{\circ} \mathrm{C}$ through 2100 under a climate sensitivity of $3{ }^{\circ} \mathrm{C}$, which corresponds to the scenario in

outsiders, we calculated the temperature for different emission pathways by using our global energy systems model DNE21+ and MAGICC without the probabilistic mode under certain climate sensitivities, i.e., 3.0 and $2.5^{\circ} \mathrm{C}$, instead of the median value under the probabilistic mode assuming the probability density function.

Figure 1 shows three emission pathways of which only figures toward 2050 are shown: The black line shows an emissions pathway with current policies (BAU), the green line shows an emissions pathway that limits temperature increase below $2{ }^{\circ} \mathrm{C}$ over the twenty first century under a climate sensitivity of $2.5^{\circ} \mathrm{C}$, which corresponds to the scenario of temporally, though slightly, overshooting $580 \mathrm{ppm} \mathrm{CO}_{2}$-eq. in AR5, and the orange line shows an emissions pathway that limits temperature increase below $2{ }^{\circ} \mathrm{C}$ over the twenty first century with a climate sensitivity of $3{ }^{\circ} \mathrm{C}$, which corresponds to the scenario where concentration stays below $500 \mathrm{ppmCO}_{2}$ eq. through 2100 . The red line shows an emissions pathway until 2030 on the assumption that the INDCs of countries that have been submitted by June 30 will be implemented. We estimated China's emissions will peak out in 2030 at 16.7 $\mathrm{GtCO}_{2}$-eq. based on its upper range of $\mathrm{CO}_{2} / \mathrm{GDP}$ improvement ratio of $65 \%$ with annual GDP growth ratio which the concentration stays below 500ppmCO 2 eq. through 2100 in AR5. Temperature is expected to stabilize below $2{ }^{\circ} \mathrm{C}$ even under a climate sensitivity of $3{ }^{\circ} \mathrm{C}$. The red line shows emissions until 2030 based on the assumption that individual country's INDCs submitted at the end of June will be implemented. We assumed China's emissions in 2030 to be $16.7 \mathrm{GtCO}_{2}$-eq. This almost corresponds to its $\mathrm{BAU}$ emissions. The US pledge covers only until 2025 and comprises two targets, i.e., 26 and $28 \%$ emissions reduction relative to 2005 . We assumed here that the $28 \%$ emission reduction will be implemented by 2025 , thereafter with a linear interpolation to $80 \%$ reduction in 2050. (Source Research Institute of Innovative Technology for the Earth)

of $6.2 \%$ through 2015-2030. For the calculation of the 2030 emissions of United States, refer to the legend to Fig. 1.

The outcome of our model shows global total emissions under major countries' INDCs (red line) in 2030 will not be on track to attain the $2{ }^{\circ} \mathrm{C}$ target if climate sensitivity is $3{ }^{\circ} \mathrm{C}$ (orange line). On the other hand, the red line emissions are in line with the green line that is consistent with the 2 degree target if climate sensitivity is $2.5^{\circ} \mathrm{C}$, and if we allow a temporal overshoot of $580 \mathrm{ppmCO}_{2}$-eq. This implies, with ECS equal to $2.5{ }^{\circ} \mathrm{C}$, that the $2{ }^{\circ} \mathrm{C}$ target is still within reach.

The authors would like to show, based on DNE21+ model, the difference of marginal abatement cost (MAC) to attain $2{ }^{\circ} \mathrm{C}$ target due to the difference of ECS. As shown in Fig. 2, MAC in 2050 is estimated to be as high as $\$ 318$ / $\mathrm{tCO}_{2}$ under ECS of $3{ }^{\circ} \mathrm{C}$, but it is merely $\$ 24 / \mathrm{tCO}_{2}$ if ECS is $2.5^{\circ} \mathrm{C}$. This implies that $2{ }^{\circ} \mathrm{C}$ target would still be a feasible target.

It is clear from the above explanations that the impact of a mere $0.5{ }^{\circ} \mathrm{C}$ difference in climate sensitivity is of critical significance for policy objectives, which is especially significant given the large uncertainties over climate sensitivity. 


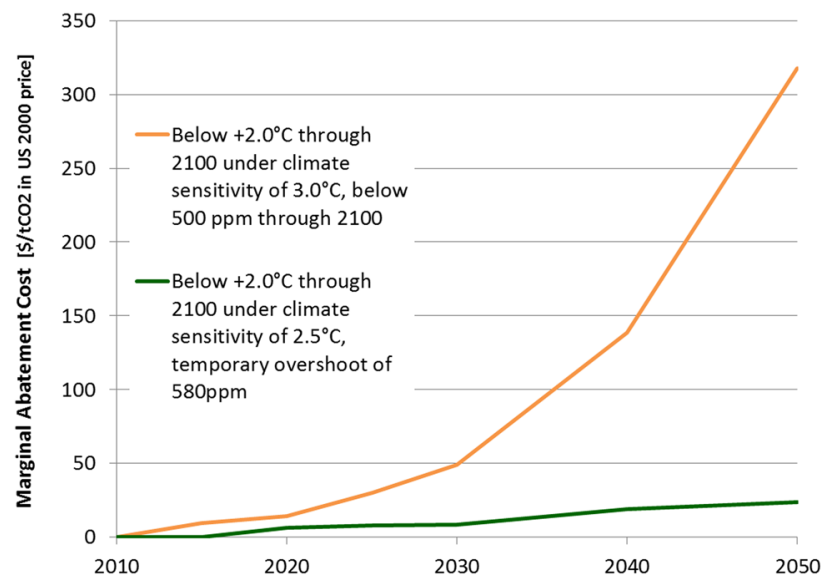

Fig. 2 Difference of Marginal Abatement Cost due to difference of ECS. The figure shows the difference of marginal abatement cost (MAC) due to difference of ECS. Both orange and green lines show MAC necessary to achieve $2{ }^{\circ} \mathrm{C}$ target (temperature stays below $2{ }^{\circ} \mathrm{C}$ since pre-industrialization through 2100). Orange line is based on the assumption that ECS would be $3{ }^{\circ} \mathrm{C}$ whereas green line is drawn on the assumption it would be $2.5^{\circ} \mathrm{C}$. MAC in 2050 in the former case is $\$ 318 / \mathrm{tCO}_{2}$ and the latter is $\$ 24 / \mathrm{tCO}_{2}$. (Source Research Institute of Innovative Technology for the Earth)

It is scientific community's vital role to narrow the uncertainty range of ECS. At the same time it is critically important for policymakers in Paris to know that they are in a position to make decisions under large uncertainty of ECS.

Acknowledgments The authors acknowledge Dr. Judith A. Curry, Georgia Institute of Technology, for her valuable comments.

\section{References}

Akimoto K (2008) Global emission reductions through a sectoral intensity target scheme. Clim Policy 8:S46-S59
Durack PJ, Gleckler PJ, Landerer FW, Taylor KE (2014) Quantifying underestimates of long-term upper-ocean warming. Nat Clim Chang 4:999-1005

IPCC (2013) Climate change 2013: The physical science basis. Contribution of Working Group I to the Fifth Assessment Report of the Intergovernmental panel on climate change. Stocker TF, Qin D, Plattner G-K, Tignor M, Allen SK, Boschung J, Nauels A, Xia Y, Bex V, Midgley PM (eds.). Cambridge University Press

IPCC (2014) Climate Change 2014: Mitigation of climate change contribution of working group III to the Fifth Assessment Report of the Intergovernmental panel on climate change. Edenhofer O, Pichs-Madruga R, Sokona Y, Farahani E, Kadner S, Seyboth K, Adler A, Baum I, Brunner S, Eickemeier P, Kriemann B, Savolainen J, Schlomer S, von Stechow C, Zwickel T, Minx JC (eds.). Cambridge University Press

Lewis N, Curry JA (2014) The implications for climate sensitivity of AR5 forcing and heat uptake estimates. Clim Dyn. doi:10.1007/ s00382-014-2342-y

Meinshausen M, Raper SCB, Wigley TML (2011) Emulating coupled atmosphere-ocean and carbon cycle models with a simpler model, MAGICC6-Part 1: model description and calibration. Atmos Chem Phys 11:1417-1456

Otto A, Otto FEL, Boucher O, Church J, Hegerl G, Forster PM, Gillett NP, Gregory J, Johnson GC, Knutti R, Lewis N, Lohmann U, Marotzke J, Myhre G, Shindell D, Stevens B, Allen MR (2013) Energy budget constraints on climate response. Nat Geosci 6:415-416

Rogelj J, Meinshausen M, Knutti R (2012) Global warming under old and new scenarios using IPCC climate sensitivity range estimates. Nat Clim Chang 2:248-253

Rogelj J, Meinshausen M, Sedlacek J, Knutti R (2014) Implications of potentially lower climate sensitivity on climate projections and policy. Environ Res Lett 9:031003. doi:10.1088/1748-9326/9/3/ 031003

Schaeffer M, Gohar L, Kriegler L, Lowe J, Riahi K, van Vuuren D (2015) Mid- and long-term climate projections for fragmented and delayed-action scenarios. Technol Forecast Soc Chang 90:257-268 